\title{
DIABETES MELLITUS IN COVID-19 PATIENTS: VERDICT OR NOT?
}

10.36740/WLek202012121

\author{
Oleksandr A. Halushko, Maryna A. Trishchynska, Tetiana M. Povietkina, Mariana V. Boliuk \\ SHUPYK NATIONAL MEDICAL ACADEMY OF POSTGRADUATE EDUCATION, KYIV, UKRAINE
}

\begin{abstract}
The aim: To investigate the causes of the negative impact of diabetes mellitus co-morbidity on the onset and development of COVID-19 in diabetic patients. Materials and methods: Electronic databases of MEDLINE and Google Scholar were searched using keyword searches.

Conclusions: 1. Diabetes mellitus is not a verdict. Diabetic patients can have COVID-19 with the same frequency as other people. And diabetes mellitus co-morbidity does not increase the probability of development COVID-19.

2. Previous diabetes can contribute the complications of COVID-19, patient's severe condition and can increase the mortality.

3. The reasons for the negative results of COVID 19 treatment in patients with diabetes may be: features of autonomic innervation in patients with diabetes, impaired function of pancreatic islet cells due to the influence of SARS-CoV-2, use of some cardiac drugs, expression of inflammatory factors due to infection.
\end{abstract}

KEY WORDS: COVID-19, diabetes mellitus, complication, prevention

Wiad Lek. 2020;73(12 p. I):2672-2676

\section{INTRODUCTION}

World Health Organization recognized coronavirus disease 2019 (COVID-19) as a pandemic on March 11, 2020 [1]. As of April 24, 2020, 2,732,702 cases of COVID-19 have been reported worldwide, resulting in 191,150 deaths [2].

The first case of COVID-19 in Ukraine was diagnosed on March 3, 2020 in Chernivtsi and the first letal case was reported on March 13, 2020. As of April 24, 2020 7,647 cases of COVID-19 have been reported in Ukraine, among these cases 193 caused death (2.52\% lethality), 601 patients ( $7.86 \%$ of cases) have recovered [2].

The feature of COVID-19 pandemics in Ukraine is that virus cause disease in women (56.0\%) more often than in men (44.0\%). But there are more male patients in other countries [2]. Although there are more male deaths (51.3\%) than female (48.7\%) in Ukraine. Deaths have occurred in 18-29 years old patients (1\%), 30-49 years old patients (14\%), in 50-69 years old patients (48\%), in 70 y.o. and older patients (38\%) [3]. $85 \%$ of all deaths were over 50 years of age. $79 \%$ of patients who died from COVID-19 had severe cardiovascular diseases, diabetes mellitus (DM), neoplasms, renal diseases, respiratory disorders and obesity. In total, co-morbidities (one or several) have been cardiovascular diseases (74\%), diabetes mellitus (22\%), lungs diseases (9\%), neoplasms (8\%), renal diseases (7\%) [3].

It has been published in Ukraine and all over the world that certain groups of patients have a risk of COVID-19 due to Severe acute respiratory syndrome coronavirus 2 (SARS-CoV-2) spreading. These are patients with arterial hypertension, cardiovascular diseases and diabetes mellitus. The main mentioned risk factors of COVID-19 are advanced age, arterial hypertension, diabetes mellitus, COPD, CVD and cerebrovascular disease [4].
Moreover, diabetes is called both a risk factor for COVID 19 , and a risk factor for respiratory failure, and a risk factor for a fatal outcome. For patients with diabetes, it's almost like a verdict. Is it true that patients with diabetes are doomed to poor results? The effort to answer this question was the purpose of this study.

\section{THE AIM}

The aim was to investigate the causes of the negative impact of diabetes mellitus co-morbidity on the onset and development of COVID-19 in diabetic patients.

\section{MATERIALS AND METHODS}

Electronic databases of MEDLINE and Google Scholar were searched using keyword searches. The search was limited to English-language literature. Keywords were COVID-19, diabetes mellitus, hyperglycemia, diabetic ketoacidosis. 136 publications were initially identified. Articles were published between December 2019 and April 24, 2020.

\section{REVIEW AND DISCUSSION}

In 12 Chinese studies included 2108 patients with confirmed COVID-19 and mean age 49.6 years the prevalence of diabetes was $10.3 \%$ [5]. For comparison, total prevalence of diabetes in China in 2013 was $10.9 \%$ and the prevalence among people aged $40-59$ years was $12.3 \%$ [6]. A similar situation is in Europe. In Padua, located at the center of an outbreak, among 146 hospitalized patients with confirmed 
Table I. The prevalence of diabetes in COVID-19 patients

\begin{tabular}{|c|c|c|c|c|c|c|}
\hline Authors & Country & $\begin{array}{c}\text { Number of } \\
\text { patients }\end{array}$ & $\begin{array}{l}\text { Sex (male/ } \\
\text { female) }\end{array}$ & Age & $\begin{array}{c}\text { Diabetic } \\
\text { patients (\%) }\end{array}$ & $\begin{array}{c}\text { Diabetic patients } \\
\text { in region (\%) }\end{array}$ \\
\hline Wang D, et al. [9] & China & 138 & $78 / 63$ & Median: 56 (42-68) & $10,1 \%$ & $\geq 9 \%^{1}$ \\
\hline Fadini GP, et al. [10] & Italy, Padua & 146 & - & Mean: 65,3 & $8,9 \%$ & $11,0 \%^{2}$ \\
\hline Wang X., et al [11] & China & 1012 & $524 / 488$ & Median: 50 (39-58) & $2,7 \%$ & $\geq 9 \%^{1}$ \\
\hline Fadini G.P., et al. [10] & China & 2108 & - & Mean: 49,6 & $10,3 \%$ & $12,3 \%^{3}$ \\
\hline $\begin{array}{c}\text { CDC COVID-19 Response } \\
\text { Team [12] }\end{array}$ & USA & 7162 & - & - & $10,9 \%$ & $\geq 9 \%$ \\
\hline Zhang JJ, et al. [13] & China & 140 & $71 / 68$ & Median: 57 (25-87) & $12,1 \%$ & $10,9 \%^{3}$ \\
\hline Guan W.J., et al. [14] & China & 1590 & $904 / 686$ & Mean: 48,9 & $8,2 \%$ & $12,3 \%^{3}$ \\
\hline Wan S., et al. [15] & China & 135 & $72 / 63$ & Median: 47 (36-55) & $8,9 \%$ & $10,9 \%^{3}$ \\
\hline Zhang MQ, et al. [16] & China & 9 & $5 / 4$ & Median: 36 (15-49) & $11,1 \%$ & $10,9 \%^{3}$ \\
\hline Guan WJ, et al. [17] & China & 1099 & $640 / 459$ & Median: 47 (25-87) & $7,37 \%$ & $10,9 \%^{3}$ \\
\hline Liu K, et al. [18] & China & 137 & $61 / 76$ & Median: 57 (20-83) & $10,22 \%$ & $10,9 \%^{3}$ \\
\hline
\end{tabular}

* - the prevalence of diabetes was investigated in certain region according to:

1 - WHO and "IDF Diabetes Atlas 2019" [19];

2 - Longato E, et al. (2020) [20];

3 - Wang L, et al.(2013) [21].

Table II. The prevalence of COVID-19 in diabetic patients due to condition severity and treatment results

\begin{tabular}{|c|c|c|c|c|c|c|c|}
\hline \multirow[t]{2}{*}{ Authors } & \multirow[t]{2}{*}{ Country } & \multirow[t]{2}{*}{$\begin{array}{c}\text { Number } \\
\text { of } \\
\text { patients }\end{array}$} & \multirow[t]{2}{*}{ Age } & \multirow[t]{2}{*}{$\begin{array}{c}\text { Mild } \\
\text { symptoms }\end{array}$} & \multicolumn{2}{|c|}{ Severe symptoms } & \multirow[t]{2}{*}{ Deaths } \\
\hline & & & & & non-ICU & $\mathrm{ICU}$ & \\
\hline Fadini GP, et al. [10] & Italy & 355 & Mediana: 80,5 (31-103) & - & - & - & $35,5 \%$ \\
\hline $\begin{array}{c}\text { CDC COVID-19 Response } \\
\text { Team [24] }\end{array}$ & USA & 7162 & & $6 \%$ & $24 \%$ & $32 \%$ & \\
\hline Bhatraju PK, et al. [25] & USA & 24 & $64 \pm 18$ & & & $58 \%$ & \\
\hline Wu J, et al. [26] & China & 280 & $43,12 \pm 19,02$ & $3,05 \%$ & & $33,73 \%$ & \\
\hline Leung C. [27] & China & 46 & 70.6 & - & - & - & $26,2 \%$ \\
\hline He XW, et al. [28] & China & 54 & Mediana: $68(59,8,74,3)$ & & $\begin{array}{r}24 \\
\text { (severe } \\
\text { cond }\end{array}$ & ritical & \\
\hline Zhou F, et al. [29] & China & 191 & Mediana: $56(46,0-67,0)$ & & $14 \%$ & & $31 \%$ \\
\hline $\begin{array}{c}\text { Korean Society of } \\
\text { Infectious Diseases [30] }\end{array}$ & $\begin{array}{l}\text { Republic of } \\
\text { Korea }\end{array}$ & 54 & Mediana: 75,5 (35-93) & - & - & - & $29,6 \%$ \\
\hline Wu C, et al. [31] & China & 201 & Mediana: 51 (43-60) & $5,1 \%$ & & $19,0 \%$ & $25,0 \%$ \\
\hline Public Health Center [3] & Ukraine & 98 & & - & - & - & $22 \%$ \\
\hline Deng SQ, et al. [32] & China & 45 & & - & - & - & $42,3 \%$ \\
\hline Zhang JJ, et al. [33] & China & 140 & Mediana: 57 (25-87) & $11,0 \%$ & $13,8 \%$ & & \\
\hline
\end{tabular}

SARS-CoV-2 infection and a mean age of 65.3 years, 13 had pre-existing diabetes (a prevalence was 8.9\%) [5]. For comparison, the prevalence of diabetes in the same region in 2018 was $6.2 \%$ overall and $11.0 \%$ among people aged 55-75 years (mean 65) [7].

According to the meta-analysis, which included 76,993 patients, the pooled prevalence of diabetes in people infected with SARS-CoV-2 was 7.87\% [8]. The data from other study, that show the prevalence of diabetes in COVID-19 patients, is in Table I.
According to this analysis we can conclude that the prevalence of diabetes in COVID-19 patients corresponds to the prevalence of DM in certain regions and in the world. So the first main conclusion of this study is that diabetes mellitus co-morbidity does not increase the probability of development COVID-19 and diabetes is not the risk factor of COVID-19.

Thus, diabetes is not a verdict, diabetic patients can have COVID-19 with the same frequency as other people. But, are there any other dangers for this patients? We reviewed data on the to discover the influence of patient's condition, 
place of treatment and diabetes co-morbidity on the results of treatment.

Wu J, et al.(2020) described in their study, which included 280 cases of COVID-19, that significantly more patients from severe group had diabetes in comparison to mild group (33.73\% vs $3.05 \%, \mathrm{P}=0,042)$ [22].

$58 \%$ of patients in ICU had diabetes; all these patients had respiratory insufficiency and $75 \%$ of patients needed mechanical ventilation [16]. Wang A, et al. (2020) in their study published other data but the trend is the same: more ICU patients with COVID-19 had diabetes than in other departments (22.2\% vs 5.9\%) [23].

According to Fadini GP, et al. (2020) the prevalence of diabetes among 355 patients who died was 35.5\%. In 2018 the prevalence of diabetes in Italy among people with the same age range and sex distribution was $20.3 \%$. Thus, the rate ratio of diabetes among patients who died from SARSCoV-2 infection compared to the general population was 1.75. The authors concluded that diabetes may not increase the risk of SARS-CoV-2 infection (we have agreed with this yet) but can worsen the outcome of this new coronavirus disease [10].

The other results of this analysis are described in Table II.

The analysis of these data allows us to conclude that patients with severe course of COVID-19 had diabetes more often. Wu C., et al.(2020) had next data: patients with mild course of disease had diabetes in $5.1 \%$ of cases, in $19 \%$ of ICU patients and in $25 \%$ of patients who died [31]. Similar data was published in American study by CDC COVID-19 Response Team. The prevalence of diabetes in this study was $6 \%$ in mild group, $24 \%$ in non-ICU severe patients and $32 \%$ in ICU patients [24]. $22 \%$ of patients who died in Ukraine had diabetes [3], while total prevalence of diabetes in Ukraine according to $\mathrm{WHO}$ is $5-6 \%$ [19].

Thus, we can make second conclusion that previous diabetes can contribute the complications of COVID-19, patient's severe condition and can increase the mortality.

We should consider why the course of infection in diabetic patients is more severe and why are the results worse (while the incidence of COVID-19 is the same in diabetic patients and people without diabetes)?

Firstly, disorders of autonomic innervation of heart (cardiac hypoesthesia syndrome) leads to afferent autonomic nerve fibers injury. These fibers conduct nerve impulses which are connected with pain due to myocardial injury. That is why silent myocardial infarction is common in diabetic patients $[34,35]$. The same situation can take place in diabetic patients with COVID-19: patients do not pay much attention to their symptoms, which leads to inadequate treatment. As a result, treatment is delayed, complications develop, the outcome is worse.

Secondly, there is information that SARS-CoV-2 can lead to temporary dysfunction of pancreatic islets [36]. There is information that coronaviruses can entry in the human cells with help of dipeptidyl peptidase 4 (DPP-4). This protein takes part in insulin modulation, glucose metabolism and glucagon degradation (as GLP-1) [37,38].
Hyperglycemia in COVID-19 patients can be caused by this or similar mechanisms [39].

The third possible reason of disease course severity is an influence of some medications often used by diabetic patients, for example, angiotensin converting enzyme (ACE) inhibitors. However, given the insufficient evidence base, the European Medicine Agency (EMA) advises do not interrupt the use of ACE inhibitors during COVID-19 pandemics [40].

Finally, diabetes is a risk factor for the progression and prognosis of COVID-19. Guo W, et al.(2020) found that COVID-19 patients without other comorbidities but with diabetes were at higher risk of severe pneumonia, release of tissue injury-related enzymes, excessive uncontrolled inflammation responses and hypercoagulable state associated with dysregulation of glucose metabolism [41]. Furthermore, serum levels of inflammation-related biomarkers such as IL-6, C-reactive protein, serum ferritin and coagulation index, D-dimer, were significantly higher ( $\mathrm{P}$ $<0.01$ ) in diabetic patients compared with those without, suggesting that patients with diabetes are more susceptible to an inflammatory reactions leading to rapid deterioration of COVID-19 [41].

All mentioned mechanisms can explain the fact that course of COVID-19 in diabetic patients is more severe and has multiple complications and worse results of treatment.

Specific measures of prophylaxis of COVID-19 in patients with diabetes:

1. People with diabetes should strictly follow these measures and avoid contacts with relatives and friends because of high possibility of COVID-19.

2. It is important that people with diabetes maintain a good glycemic control, as it might help in reducing the risk of infection and also the severity. More frequent monitoring of blood glucose levels (with use of self-monitoring blood glucose) is required Good glycemic control may decrease chances of superadded bacterial pneumonia.

3. Patients with diabetes should continue to use antihypertensive drugs, for example ACE inhibitors (the recommendation can change according to $\mathrm{WHO}$ ).

4. Attention to nutrition and adequate protein intake is important. Any deficiencies of minerals and vitamins need to be corrected. Delivery of food and drugs should be organized during quarantine.

5. Patients with diabetes should do exercise regularly at home during quarantine.

6. Patients should be in contact with endocrinologist and general practitioner. Face-to-face meeting in hospitals are not recommended to diabetic patients because of crowding.

7. We recommend to use phone calls, video-calls, e-mails to maintain the contact with medical team for disease controlling.

8. Patients with diabetes are recommended to plan their actions in case of COVID-19. It is important to have enough means for frequent monitoring of blood glucose at home. 


\section{CONCLUSIONS}

1. Diabetes mellitus is not a verdict. Diabetic patients can have COVID-19 with the same frequency as other people. And diabetes mellitus co-morbidity does not increase the probability of development COVID-19.

2. Previous diabetes can contribute the complications of COVID-19, patient's severe condition and can increase the mortality.

3. The reasons for the negative results of COVID 19 treatment in patients with diabetes may be: features of autonomic innervation in patients with diabetes, impaired function of pancreatic islet cells due to the influence of SARS-CoV-2, use of some cardiac drugs, expression of inflammatory factors due to infection.

Based on our own experience and analysis of international publications $[34,42,43]$, we consider it necessary to formulate recommendations for diabetes patients in the context of the COVID 19.

\section{REFERENCES}

1. World Health Organization. WHO Director-General's opening remarks at the media briefing on COVID-19-11 March 2020. Geneva, Switzerland: World Health Organization; 2020. https://www.who.int/dg/speeches/ detail/who-director-general-s-opening-remarks-at-the-mediabriefingon-covid-19---11-march-2020.

2. Coronavirus in Ukraine. https://index.minfin.com.ua/ua/reference/ coronavirus/ukraine/

3. The Center for Public Health of the Ministry of Health of Ukraine Operative information. https://phc.org.ua/kontrol-zakhvoryuvan/ inshi-infekciyni-zakhvoryuvannya/koronavirusna-infekciya-covid-19

4. Wang B., Li R., Lu Z., Huang Y. Does comorbidity increase the risk of patients with COVID-19: evidence from meta-analysis. Aging (Albany NY). 2020;12. doi: 10.18632/aging.103000.

5. Fadini G.P., Morieri M.L., Longato E., Avogaro A. Prevalence and impact of diabetes among people infected with SARS-CoV-2.J Endocrinol Invest. 2020. doi:10.1007/s40618-020-01236-2.

6. Wang L., Gao P., Zhang M. et al. Prevalence and Ethnic Pattern of Diabetes and Prediabetes in China in 2013. JAMA. 2017;317(24):25152523. doi: 10.1001/jama.2017.7596.

7. Longato E., Di Camillo B., Sparacino G., Saccavini C. et al. Diabetes diagnosis from administrative claims and estimation of the true prevalence of diabetes among 4.2 million individuals of the Veneto region (North East Italy). Nutr Metab Cardiovasc Dis. 2020;30(1):84-91. doi: 10.1016/j.numecd.2019.08.017.

8. Emami A., Javanmardi F., Pirbonyeh N., Akbari A. Prevalence of Underlying Diseases in Hospitalized Patients with COVID-19: a Systematic Review and Meta-Analysis. Arch Acad Emerg Med. 2020;8(1):e35.

9. Wang D., Hu B., Hu C. et al. Clinical Characteristics of 138 Hospitalized Patients With 2019 Novel Coronavirus-Infected Pneumonia in Wuhan, China. JAMA. 2020. doi: 10.1001/jama.2020.1585.

10. Fadini G.P., Morieri M.L., Longato E., Avogaro A. Prevalence and impact of diabetes among people infected with SARS-CoV-2. J Endocrinol Invest. 2020. doi: 10.1007/s40618-020-01236-2.

11. Wang X., Fang J., Zhu Y. et al. Clinical characteristics of non-critically ill patients with novel coronavirus infection (COVID-19) in a Fangcang Hospital. Clin Microbiol Infect. 2020 Apr 3. pii: S1198-743X(20)30177-4. doi: 10.1016/j.cmi.2020.03.032.
12. CDC COVID-19 Response Team. Preliminary Estimates of the Prevalence of Selected Underlying Health Conditions Among Patients with Coronavirus Disease 2019 - United States, February 12-March 28, 2020. MMWR Morb Mortal Wkly Rep. 2020;69(13):382-386. doi: 10.15585/ mmwr.mm6913e2.

13. ZhangJ.J.,DongX., Cao Y.Y. etal.Clinical characteristics of 140 patients infected with SARS-CoV-2 in Wuhan, China. Allergy. 2020. doi: 10.1111/all.14238.

14. Guan W.J., Liang W.H., Zhao Y. et al; China Medical Treatment Expert Group for Covid-19. Comorbidity and its impact on 1590 patients with Covid-19 in China: A Nationwide Analysis. Eur Respir J. 2020. pii: 2000547. doi: 10.1183/13993003.00547-2020.

15. Wan S., Xiang Y., Fang W. et al. Clinical features and treatment of COVID-19 patients in northeast Chongqing. J Med Virol. 2020. doi: 10.1002/jmv.25783.

16. Zhang M.Q., Wang X.H., Chen Y.L. et al. [Clinical features of 2019 novel coronavirus pneumonia in the early stage from a fever clinic in Beijing]. Zhonghua Jie He He Hu Xi Za Zhi. 2020;43(3):215-218. doi: 10.3760/ cma.j.issn.1001-0939.2020.03.015.

17. Guan W.J., Ni Z.Y., HuY. et al.; China Medical Treatment Expert Group for Covid-19. Clinical Characteristics of Coronavirus Disease 2019 in China. N Engl J Med. 2020. doi: 10.1056/NEJMoa2002032.

18. Liu K., Fang Y.Y., Deng Y. et al. Clinical characteristics of novel coronavirus cases in tertiary hospitals in Hubei Province. Chin Med J (Engl). 2020. doi: 10.1097/CM9.0000000000000744.

19. IDF Diabetes Atlas.9th Edition 2019. https://www.diabetesatlas.org/en/

20. Longato E., Di Camillo B., Sparacino G., Saccavini C. et al. Diabetes diagnosis from administrative claims and estimation of the true prevalence of diabetes among 4.2 million individuals of the Veneto region (North East Italy). Nutr Metab Cardiovasc Dis. 2020 Jan 3;30(1):84-91. doi: 10.1016/j.numecd.2019.08.017.

21. Wang L., Gao P., Zhang M. et al. Prevalence and Ethnic Pattern of Diabetes and Prediabetes in China in 2013. JAMA. 2017;317(24):25152523. doi: 10.1001/jama.2017.7596.

22. Wu J., Li W., Shi X. et al. Early antiviral treatment contributes to alleviate the severity and improve the prognosis of patients with novel coronavirus disease (COVID-19). J Intern Med. 2020. doi: 10.1111/joim.13063.

23. Wang A., Zhao W., Xu Z., Gu J. Timely blood glucose management for the outbreak of 2019 novel coronavirus disease (COVID-19) is urgently needed. Diabetes Res Clin Pract. 2020;162:108118. doi: 10.1016/j. diabres.2020.108118.

24. CDC COVID-19 Response Team. Preliminary Estimates of the Prevalence of Selected Underlying Health Conditions Among Patients with Coronavirus Disease 2019 - United States, February 12-March 28, 2020. MMWR Morb Mortal Wkly Rep. 2020;69(13):382-386. doi: 10.15585/ mmwr.mm6913e2.

25. Bhatraju P.K., Ghassemieh B.J., Nichols M. et al. Covid-19 in Critically III Patients in the Seattle Region - Case Series. N Engl J Med. 2020 Mar 30. doi: 10.1056/NEJMoa2004500.

26. Wu J., Li W., Shi X. et al. Early antiviral treatment contributes to alleviate the severity and improve the prognosis of patients with novel coronavirus disease (COVID-19). J Intern Med. 2020. doi: 10.1111/ joim. 13063.

27. Leung C. Clinical features of deaths in the novel coronavirus epidemic in China. Rev Med Virol. 2020:e2103. doi: 10.1002/rmv.2103.

28. HeX.W., Lai J.S., Cheng J. et al. [Impact of complicated myocardial injury on the clinical outcome of severe or critically ill COVID-19 patients]. Zhonghua Xin Xue Guan Bing Za Zhi. 2020 Mar 15;48(0):E011. doi: 10.3760/cma.j.cn112148-20200228-00137. 
29. Zhou F., Yu T., Du R. et al. Clinical course and risk factors for mortality of adult inpatients with COVID-19 in Wuhan, China: a retrospective cohort study. Lancet. 2020;395(10229):1054-1062. doi: 10.1016/ S0140-6736(20)30566-3.

30. Korean Society of Infectious Diseases and Korea Centers for Disease Control and Prevention. Analysis on 54 Mortality Cases of Coronavirus Disease 2019 in the Republic of Korea from January 19 to March 10, 2020. J Korean Med Sci. 2020;35(12):e132. doi: 10.3346/jkms.2020.35. e132.

31. Wu C., Chen X., CaiY. et al. Risk Factors Associated With Acute Respiratory Distress Syndrome and Death in Patients With Coronavirus Disease 2019 Pneumonia in Wuhan, China. JAMA Intern Med. 2020. doi: 10.1001/ jamainternmed.2020.0994.

32. Deng S.Q., Peng H.J. Characteristics of and Public Health Responses to the Coronavirus Disease 2019 Outbreak in China. J Clin Med. 2020;9(2). pii:E575. doi: 10.3390/jcm9020575.

33. Zhang J.J., Dong X., Cao Y.Y. et al. Clinical characteristics of 140 patients infected with SARS-CoV-2 in Wuhan, China. Allergy. 2020. doi: 10.1111/ all.14238.

34. Maddaloni E., Buzzetti R. Covid-19 and diabetes mellitus: unveiling the interaction of two pandemics. Diabetes Metab Res Rev. 2020:e33213321. doi: 10.1002/dmrr.3321.

35. Fu R., Li S.D., Song C.X. et al. Clinical significance of diabetes on symptom and patient delay among patients with acute myocardial infarction-an analysis from China Acute Myocardial Infarction (CAMI) registry. J Geriatr Cardiol. 2019 May;16(5):395-400. doi: 10.11909/j. issn.1671-5411.2019.05.002.

36. Yang J.K., Lin S.S., Ji X.J., Guo L.M. Binding of SARS coronavirus to its receptor damages islets and causes acute diabetes. Acta Diabetol 2010;47:193-9. doi: 10.1007/s00592-009-0109-4.

37. Kleine-Weber H., Schroeder S., Krüger N. et al. Polymorphisms in dipeptidyl peptidase 4 reduce host cell entry of Middle East respiratory syndrome coronavirus. Emerg Microbes Infect. 2020;9(1):155-168. doi: 10.1080/22221751.2020.1713705.

38. Raj V.S., Mou H., Smits S.L. et al. Dipeptidyl peptidase 4 is a functional receptor for the emerging human coronavirus-EMC. Nature. 2013;495(7440):251-4. doi: 10.1038/nature12005.

39. Ilias I., Zabuliene L. Hyperglycemia and the novel Covid-19 infection: Possible pathophysiologic mechanisms. Med Hypotheses. 2020;139:109699. doi: 10.1016/j.mehy.2020.109699.
40. EMA advises continued use of medicines for hypertension, heart or kidney disease during COVID-19 pandemic. https://www.ema.europa. eu/en/ news/ema-advises-continued-use-medicines-hypertensionheart-kidney-disease-during-covid-19-pandemic

41. Guo W., Li M., Dong Y. et al. Diabetes is a risk factor for the progression and prognosis of COVID-19. Diabetes Metab Res Rev. 2020:e3319. doi:10.1002/dmrr.3319.

42. Gupta R., Ghosh A., Singh A.K., Misra A. Clinical considerations for patients with diabetes in times of COVID-19 epidemic. Diabetes Metab Syndr. 2020;14(3):211-212. doi: 10.1016/j.dsx.2020.03.002.

43. Puig-Domingo M., Marazuela M., Giustina A. COVID-19 and endocrine diseases. A statement from the European Society of Endocrinology. Endocrine. 2020. doi: 10.1007/s12020-020-02294-5.

\section{ORCID and contributionship:}

Oleksandr A. Halushko: 0000-0001-7027-8110 A, B, F

Maryna A. Trishchynska: 0000-0002-1022-0635 B,D

Tetiana M. Povietkina: 0000-0002-9442-2188 D,E

Mariana V. Boliuk: 0000-0002-9394-4179 E,F

\section{Conflict of interest:}

The Authors declare no conflict of interest.

\section{CORRESPONDING AUTHOR Oleksandr A. Halushko}

Shupyk National Medical Academy of Postgraduate Education, 9 Dorohozhytska st., 04112 Kyiv, Ukraine

tel:+38095 4815577

e-mail: 0.halushko@ukr.net

Received: 22.08 .2020

Accepted: 30.10 .2020

A - Work concept and design, B - Data collection and analysis, C - Responsibility for statistical analysis, $\mathbf{D}$-Writing the article, $\mathbf{E}$-Critical review, $\mathbf{F}$ - Final approval of the article 